\section{Marine pollution}

Delegates to the Inter-Governmental Maritime Consultative Organisation, meeting in Acapulco this week to discuss marine pollution from ships, will consider UK Government reports which survey national and international counter-pollution arrangements and outline UK contingency plans to tackle major oil spills in territorial waters. While claiming that existing UK measures have already proved partially successful in dispersing a 300-tonne spill in the English Channel last November, the reports stress the need for improved international cooperation. Discussions b e t w e e $n$ France, Norway and Britain are already under way.

\section{Anders move}

In a surprise announcement, President Ford last week nominated William A. Anders, Chairman of the Nuclear Regulatory Commission (NRC), to be ambassador to Norway. Anders, a for-

THE delights of tobacco were recorded in the panegyric "My Lady Nicotine" by James Barric. Perhaps he should instead have used the word "nitrosamine", as the grande dame who lurks in the fragrant weed. $N^{\prime}$-nitrosonornicotine (NNN) was identified by Hoffmann and coworkers in unburned tobacco at levels ranging from 2 to 89 parts per million. Most samples contained about 4 p.p.m. This may be compared with about one four-hundredth of this level of nitrosopyrrolidine in bacon, a commodity that is now figuratively as well as literally in the frying-pan for its content of nitrosamines. NNN induces multiple pulmonary adenomas in mice, but just how much of the carcinogenic effect of cigarettes is caused by nitrosamines is not known. The smoke from one cigarette contained 0.14 microgram of NNN, which is non-volatile, and other nitrosamines that are volatile. The well-televised habit of chewing tobacco is familiar to all baseball fans, but I have seen no epidemiological studics on pitchers.

A few weeks ago my lady nicotine (or nitrosamine) came knocking at my door in the guise of a letter from Mr William D. Hobbs, the chairman of the board of the R. J. Reynolds Tobacco Company. I was, he told me, a leader in my community, and, therefore, I would want to know about a technological achievement consisting of a new cigarettc, which "draws free and easy" (sic). If I were not a smoker, he said, I might wish to refer this mer astronaut, established a reputation as a tough administrator during the first year of the commission's activities as watchdog over the nuclear industry. Ford indicated that he would nominate Marcus A. Rowden, a former general counsel to the Atomic Energy Commission and a member of the NRC, to succeed Anders.

\section{Cyclamate view}

A committee of cancer experts in the USA has failed to reach a definitive conclusion about whether or not the banned artificial sweetener cyclamate is a carcinogen. The committee, appointed by the National Cancer Institute to help the Food and Drug Administration decide whether to lift the ban on cyclamate, noted that most of the tests leading to a significant increase in tumours in cyclamate-treated animals have employed dubious procedures or used strains of animals which have a large incidence of spontaneous tumours, but said the results were a cause for concern.

offer of two packages of cigarettes to someone who I thought might be interested. I told him I had a better idea. I believed that all advertising of cigarettes should stop, and that direct

\section{My lady nicotine}

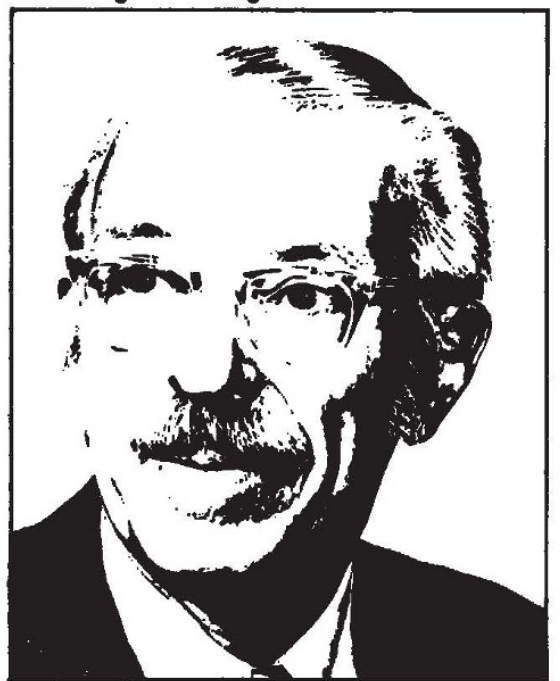

THOMAS H. JUKES

mail advertising to start someone in the habit of smoking was particularly pernicious.

My answer to this came from a company executive, Mr Crohn, presumably assigned by $\mathrm{Mr}$ Hobbs to respond to anti-cigarette cranks. $\mathrm{He}$ sent a letter, and various picces of literature favouring cigarettes. One

\section{UK chemical industry}

Following last week's National Economic Development Office report urging the UK chemical industry, now at "a decisive point", to reassess existing rates of investment and bring forward planned projects so as to improve international competitiveness beyond 1978, an independent publication from the Chemical Industries Association (CIA) has called on the Government to boost managerial confidence by easing the price and profit controls cutting into available revenue at a time when investment demands are three times higher than in 1974. The CIA report says that the industry's plans to spend $£ 2,800$ millions on new plant and equipment over the next three years indicate a willingness to meet projected market demands. The difficulties faced by the industry were simultaneously underlined by the publication of a third report, showing that several leading chemical companies have been trading at a real loss over the past three years.

item was an article reprinted from Executive Health, a well-advertised publication that sends out appeals for funds to support an Institute for Orthomolecular Medicine. The article was entitled "The Case Against Tobacco Is Not Closed. Why smoking may not be 'dangerous to your health" ". Good health, executives! $\mathrm{Mr}$ Crohn's letter told me that if advertising of cigarettes were to cease, then "the public would never know that low tar and nicotine cigarettcs, which many persons desire, are available in the market place".

The phrase "which many persons desire" rang a faint mnemonic bell of the first casket scene in The Merchant of Venice-written before men were persons and coffins were caskets. In this scene, the gold casket has the inscription "Who chooseth me shall gain what many men desire". Upon reading this, the Prince of Morocco says, "Why, that's the lady: all the world desires her". Was Mr Crohn a crypto-Shakespearean? Did he mean many persons desire My Lady Nicotine? But then, in the play, the casket is opened to reveal

"A carrion Death, within whose empty eye

There is a written scroll!"

The scroll, I mused, perhaps said, "Warning: The Surgeon General has determined that cigarette smoking is dangerous to your health".

We shall never know. The warning was written in letters too small to read. 